Національна медична академія післядипломної освіти імені П. Л. Шупика

\title{
вПлИв ХІРУРГІчної СТИМУляції ОвУляції шляХОМ ФЕРТИЛОСКОПІЧНОГО ОВАРІАЛЬНОГО ДРИЛІНГУ НА ГОРМОНАЛЬНИЙ СТАТУС ПАЦІЕНТОК ІЗ КЛОМІФЕН-РЕЗИСТЕНТНОЮ ФОРМОЮ СИНДРОМУ ПОЛІКІСТОЗНИХ ЯЕЧНИКІВ ТА ОЖИРІННЯМ
}

Мета дослідження - вивчити вплив хірургічної стимуляції овуляції шляхом фертилоскопічного оваріального дрилінгу на гормональний статус пацієнток із кломісрен-резистентною формою синдрому полікістозних яєчників (СПКя) та ожирінням.

Матеріали та методи. Під спостереженням перебувала 61 жінка репродуктивного віку. В основну групу ввійшла 31 жінка із кломіфен-резистентним СПкя і з індексом маси тіла $>30$ кг/м², яким хірургічну стимуляцію овуляції виконано 3 використанням ТВГЛ у Київському міському центрі репродуктивної та перинатальної медицини за період 2017-2019рр. У контрольну групу увійшли 30 умовно соматично і гінекологічно здорових жінок. Пацієнтки пройшли комплексне обстеження. Концентрації гонадотропінів, статевих стероїдів та антимюллерового гормону в сироватці перисреричної крові досліджували імунохімічним методом на 2-3-й день менструального циклу перед операцією, через 1, 3 і 6 місяців після операції.

Результати дослідження та їх обговорення. Після проведення хірургічної стимуляції відмічали поліпшення гормонального профрілю сироватки периферичної крові зі зниженням лютеїнізуючого гормону, статевих стероїдів та підвищенням солікулостимулюючого гормону, але через 3 місяці спостерігали тенденцію до поступового повернення вмісту гонадотропінів та статевих стероїдів до вихідного передопераційного рівня. Через 6 місяців після хірургічної стимуляції овуляції найбільш стійкими залишалися зниження порівняно з контрольними значеннями сироваткової концентрації антимюллерового гормону в 1,24 ( $<<0,01)$, вільного тестостерону - в 1,61 ( $<<0,01)$ і дегідроепіандростерону - в 1,69 раза $(p<0,01)$. Поліпшення гормонального статусу безпосередньо після хірургічної стимуляції овуляції привело до настання у прооперованих пацієнток вагітності впродовж 3 місяців у 26,81 \% випадків, впродовж 6 місяців - у 35,48 \%.

Висновок. Отримані дані вказують на те, що перші 6 місяців після хірургічної стимуляції овуляції $€$ найбільш перспективними для планування і настання вагітності у кломіфен-резистентних пацієнток із СПкЯ і ожирінням.

Ключові слова: синдром полікістозних яєчників; ожиріння; безпліддя; резистентність до кломісену; хірургічна стимуляція овуляції; фрертилоскопічний оваріальний дрилінг; гонадотропіни; статеві стероїди; антимюллерів гормон.

ВЛИЯНИЕ ХИРУРГИЧЕСКОЙ СТИМУЛЯЦИИ ОВУЛЯЦИИ ПУТЕМ ФЕРТИЛОСКОПИЧЕСКОГО ОВАРИАЛЬНОГО ДРИЛЛИНГА НА ГОРМОНАЛЬНЫЙ СТАТУС ПАЦИЕНТОК С КЛОМИФЕН-РЕЗИСТЕНТНОЙ ФОРМОЙ СИНДРОМА ПОЛИКИСТОЗНЫХ ЯИЧНИКОВ И ОЖИРЕНИЕМ

Цель исследования - изучить влияние хирургической стимуляции овуляции путём фертилоскопического овариального дриллинга на гормональный статус пациенток с кломисен-резистентной формой СпКЯ и ожирением.

Материалы и методы. Под наблюдением находилась 61 женщина репродуктивного возраста. В основную группу вошла 31

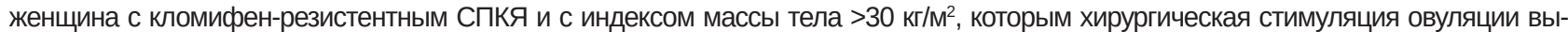
полнена с использованием ТВГЛ в Киевском городском центре репродуктивной и перинатальной медицины за период 2017-2019 гг. В контрольную группу вошли 30 условно соматически и гинекологически здоровых женщин. Пациентки прошли комплексное обследование. Концентрации гонадотропинов, половых стероидов и антимюллерова гормона в сыворотке периферической крови исследовали иммунохимическим методом на 2-3-й день менструального цикла перед операцией, через 1, 3 и 6 месяцев после операции.

Результаты исследования и их обсуждение. После проведения хирургической стимуляции отмечалось улучшение гормонального профиля сыворотки периферической крови со снижением лютеинизирующего гормона, половых стероидов и повышением фолликулостимулирующего гормона, но через 3 месяца наметилась тенденция к постепенному возвращению содержания гонадотропинов и половых стероидов к исходному предоперационному уровню. Через 6 месяцев после хирургической стимуляции овуляции наиболее устойчивыми оставались снижения по сравнению с контрольными значениями концентрации в сыворотке крови антимюллерова гормона в 1,24 раза ( $<0,01)$, свободного тестостерона - в $1,61(p<0,01)$ и дегидроэпиандростерона - в 1,69 раза $(p<0,01)$. Улучшение гормонального статуса непосредственно после хирургической стимуляции овуляции привело к наступлению у прооперированных пациенток беременности в течение 3 месяцев в 26,81 \% случаев, в течение 6 месяцев - в 35,48 \%.

Вывод. Полученные данные указывают на то, что первые 6 месяцев после хирургической стимуляции овуляции являются наиболее перспективными для планирования и наступления беременности у кломисрен-резистентных пациенток с СПКЯ и ожирением.

Ключевые слова: синдром поликистозных яичников; ожирение; бесплодие; резистентность к кломисрену; хирургическая стимуляция овуляции; фрертилоскопический овариальный дриллинг; гонадотропины; половые стероиды; антимюллеров гормон.

EFFECT OF SURGICAL STIMULATION OF OVULATION BY FERTILOSCOPIC OVARIAL DRILLING TO HORMONAL STATUS OF PATIENTS WITH CLOMIPHENE-RESISTANT POLYCYSTIC OVARIAN SYNDROME AND OBESITY

The aim of the study - to learn the influence of surgical stimulation of ovulation by fertiloscopic ovarian drilling on the hormonal status of patients with clomiphene-resistant PCOS and obesity. 
Materials and Methods. 61 women of reproductive age were under observation. The main group included 31 women with clomiphene-resistant PCOS and body mass index $>30 \mathrm{~kg} / \mathrm{m}^{2}$, who underwent surgical stimulation of ovulation using transvaginal hydrolaparoscopy in the Kyiv City Center for Reproductive and Perinatal Medicine for the period from 2017-2019. The control group included 30 conditionally somatically and gynecologically healthy women. The patients underwent a comprehensive examination. The concentration of gonadotropins, sex steroids and anti-Müllerian hormone in the serum of peripheral blood was investigated by the immunochemical method on days 2-3 of the menstrual cycle before the operation, 1, 3 and 6 months after the operation.

Results and Discussion. After surgical stimulation, there was an improvement in the hormonal profile of the peripheral blood serum with a decrease in luteinizing hormone, sex steroids, and an increase in follicle-stimulating hormone, but after 3 months there was a tendency towards a gradual return of the content of gonadotropins and sex steroids to the initial preoperative level 6 months after surgical stimulation of ovulation, the most stable decrease in comparison with the control values of the concentration of anti-Müllerian hormone in blood serum by 1.24 times $(p<0.01)$, free testosterone - by $1.61(p<0.01)$ and dehydroepiandrosterone -1.69 times $(p<0.01)$. An improvement in the hormonal status immediately after surgical stimulation of ovulation led to the onset of pregnancy in the operated patients within 3 months in $26.81 \%$ of cases, within 6 months - in $35.48 \%$.

Conclusion. The data obtained indicate that the first 6 months after surgical stimulation of ovulation are the most promising for planning and the onset of pregnancy in clomiphene-resistant patients with PCOS and obesity.

Key words: polycystic ovary syndrome; obesity; infertility; clomiphene resistance; surgical stimulation of ovulation; fertiloscopic ovarian drilling; gonadotropins; sex steroids; anti-Müllerian hormone.

ВСтУП. Синдром полікістозних яєчників (СПкЯ) - найбільш часте ендокринологічне та метаболічне порушення, про яке повідомляють жінки репродуктивного віку [6, 10]. У глобальному масштабі частота цього синдрому варіює від 6 до 20 \% [2, 20] залежно від застосовуваних діагностичних критеріїв, із більш високою поширеністю серед жінок із надмірною масою або ожирінням і в певних етнічних групах $[17,24]$.

СПКЯ є складною і гетерогенною ендокринопатією, що характеризується сукупністю симптомів та клінічних ознак, включаючи гіперандрогенізм (клінічний або біохімічний), хронічну ановуляцію і морфологію полікістозних яєчників [6]. В даний час існує декілька діагностичних критеріїв СПКЯ, в яких використовуються різні комбінації цих клінічних ознак. Відповідно до Роттердамських критеріїв, найбільш широко використовуваний для клінічної діагностики СПКЯ визначається як мінімум двома з трьох вищезазначених клінічних ознак [16, 22]. СПКЯ вважається провідною причиною ановуляторного безпліддя [5, 8] і тому клінічно асоціюється зі зниженою репродуктивною функцією. Однак згубний вплив цієї патології не обмежується репродуктивною недостатністю, також часто порушується і метаболічна фрункція $[2,4]$. Жінки із СпкЯ мають підвищений ризик розвитку цукрового діабету II типу, ожиріння і гіпертензії [5, 8, 23]. Близько 30-70 \% жінок, що належать до різних етнічних груп, страждають від СПКЯ, ожиріння [7, 18, 19].

Хірургічна стимуляція овуляції є другим етапом лікування безпліддя у кломіфен-резистентних жінок із СПкя $[11,12,26]$. Перевагу віддають ендохірургічним методикам. При ожирінні виникають деякі технічні труднощі при виконанні лапароскопії, пов'язані $з$ тим, що у пацієнтів збільшується відстань між шкірою і апоневрозом, апоневрозом та очеревиною, змінюється співвідношення між пупком і біфуркацією аорти, потрібні спеціальні троакари [1]. Існують певні труднощі та ризики при накладанні карбоксиперитонеуму при розташуванні хворої у положенні Тределенбурга. У цьому ракурсі сьогодні ендохірурги знову звертаються до методик трансвагінальної гідролапароскопії (ТВГЛ) або фрертилоскопії [9, 13, 21, 22], запропонованих S. Gordts et al. (1998) [25] та A. Watrelot et al. (1999) [27].

МЕТА ДОСЛІДЖЕННЯ - вивчити вПлив хірургічної стимуляції овуляції шляхом фертилоскопічного оварі- ального дрилінгу на гормональний статус пацієнток із кломіфрен-резистентною формою СПКЯ та ожирінням.

МАТЕРІАЛИ ТА МЕТОДИ. Під спостереженням перебувала 61 жінка репродуктивного віку. В основну групу ввійшла 31 жінка із кломіфен-резистентним СПкя і 3

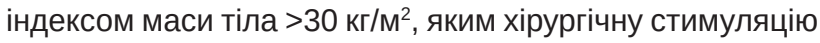
овуляції виконано з використанням ТВГЛ у Київському міському центрі репродуктивної та перинатальної медицини за період 2017-2019рр. У контрольну групу увійшли 30 умовно соматично і гінекологічно здорових жінок.

При загальному клінічному обстеженні хворих вивчали дані соціально-економічного статусу, гінекологічного, акушерського, соматичного, іноректологічного й алергологічного анамнезу. Усім жінкам були проведені повне клініко-лабораторне дослідження й обстеження на урогенітальні інфекції, консультації терапевта, ендокринолога. Антропометричне дослідження включало оцінку індексу маси тіла і вираження гірсутного синдрому за гормональною шкалою Феррімана-Галвея.

Концентрації таких гормонів, як лютеїнізуючий (ЛГ), фолікулостимулюючий (ФСГ), пролактин (ПРЛ), вільний тестостерон (ТВ), андростендіон (АС), дегідроепіандростерону сульфрат (ДГЕАС), естрадіол (Е2), антимюллерів гормон (АМГ), у сироватці периферичної крові досліджували на автоматичному аналізаторі Cobas-e411 (Roche Diagnostic, Швейцарія) при застосуванні імунохімічного методу з електрохемілюмінесцентною детекцією та реактивів фрірми Roche Diagnostic (Швейцарія) на 2-3-й день менструального циклу перед операцією, через 1, 3 і 6 місяців після операції.

УЗД проводили із використанням апарата SSA-790A (APLIO-XG) (Toshiba, Японія) та трансабдомінального і трансвагінального конвексних датчиків.

ТВГЛ проводили в умовах стаціонару одного дня під внутрішньовенним знеболюванням, і вона базувалася на використанні вагінального доступу, режиму гідросрлтації та мікрохірургічної ендоскопічної техніки. Розтягнення порожнини малого таза досягали введенням підігрітого розчину лактату Рінгера. Усі оперативні втручання проводили в першій фразі оваріального циклу. Робили по 6-8 дрібних отворів переважно на передньобоковій стороні кожного яєчника. Здійснювали ТВГЛ та гістероскопію під час одного й того ж знеболювання. Як антибіотикопрофрі- 
лактику пацієнткам призначали по 1000 мг амоксициліну інтраопераційно.

При статистичній обробці матеріалу визначали середнє значення (M) та похибку стандартного відхилення (SE), t-критерій Стьюдента для порівняння параметричних показників.

РЕЗУЛЬТАТИ ДОСЛІДЖЕННЯ ТА ЇХ ОБГОВОРЕННЯ. Вік досліджуваних жінок перебував у межах від 19 до 35 років, склав у групі СПкя $(25,74 \pm 0,78)$ року, у контролі - $(26,23 \pm 0,47)$ року. Індекс маси тіла у середньому дорівнював, відповідно, $(34,64 \pm 0,81)$ і $(20,81 \pm 0,26)$ кг/м² $(\mathrm{p}<0,01)$. Гірсутне число за шкалою Ферімана-Галвея склало $(10,97 \pm 0,48)$ і $(2,90 \pm 0,27)$ бала $(p<0,01)$. Аналіз менструальної фрункції показав, що вік менархе складав у жінок із СПкЯ та ожирінням $(13,13 \pm 0,21)$ року проти $(12,57 \pm 0,13)$ року в контролі $(p<0,05)$; тривалість менструації - $(6,10 \pm 0,14)$ проти $(5,37 \pm 0,18)$ дня $(p<0,01)$; середня тривалість менструального циклу - $(48,74 \pm 5,61)$ проти $(28,70 \pm 0,27)$ дня $(p<0,01)$; середня кількість менструальних циклів на рік - $(6,65 \pm 0,49)$ проти $(12,00 \pm 0,01)$ $(p<0,01)$. Тривалість безпліддя у прооперованих жінок із СПкЯ становила в середньому $(5,23 \pm 0,64)$ року. Яєчники при СПКЯ були білатерально збільшені, середній об'єм правого яєчника дорівнював $(15,95 \pm 0,94) \mathrm{cm}^{3}$, лівого $(13,92 \pm 0,56) \mathrm{cm}^{3}$, тоді як у контролі $(3,93 \pm 0,13) \mathrm{cm}^{3}(\mathrm{p}<0,01)$ і $(3,72 \pm 0,13)$ см$^{3}(p<0,01)$. Усі жінки із СПКЯ отримували кломіфену цитрат впродовж 3-6 місяців і не мали відновлення овуляції. У чоловіків прооперованих жінок із СПкя була нормозооспермія.

Гормональний профріль пацієнток із кломіфен-резистентним СПКЯ та ожирінням характеризувався до операції підвищеним відносно контрольних показників рівнем ЛГ в 1,87 раза $((9,91 \pm 0,33)$ проти $(5,30 \pm 0,18) \mathrm{MO} / л, \mathrm{p}<0,01)$, ФСГ - в 1,29 раза $((5,11 \pm 0,20)$ проти $(3,95 \pm 0,17) \mathrm{MO} / л$ $\mathrm{p}<0,01)$, коефіцієнта співвідношення ЛГ/ФСГ - в 1,39 раза $((2,00 \pm 0,09)$ проти $(1,44 \pm 0,09), \mathrm{p}<0,01), \mathrm{E}_{2}-$ в 1,47 раза $((61,09 \pm 3,95)$ проти $(41,59 \pm 2,33)$ пг/мл, $р<0,01), \mathrm{T}_{\text {в }}$

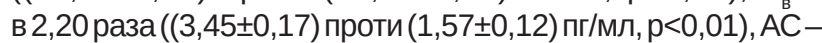
в 1,88 раза $((2,97 \pm 0,18)$ проти $(1,56 \pm 0,06)$ нг/мл, p<0,01), ДГЕАС - в 2,88 раза $((281,5 \pm 19,3)$ проти $(97,7 \pm 6,0)$ мкг/дл, $\mathrm{p}<0,01)$, АМГ - в 2,96 раза $((6,83 \pm 0,22)$ проти $(2,31 \pm$ $0,05)$ нг/мл, $p<0,01)$.
Як видно з таблиці 1, через місяць після хірургічної стимуляції овуляції у всіх обстежених пацієнток із кломіфрен-резистентною формою СПКЯ на 2-3-й день менструального циклу знизився вміст у сироватці крові лГ в 1,21 раза (до $(8,20 \pm 0,21) \mathrm{MO/мл,} \mathrm{p}<0,01)$, коефріцієнта співвідношення ЛГ/ФСГ - в 1,48 раза (до $(1,36 \pm 0,04)$, p>0,05), $E_{2}-$ в 1,34 раза (до $(45,65 \pm 0,95)$ пг/мл, p>0,05), $\mathrm{T}_{\mathrm{B}}-1,84$ раза (до $(1,88 \pm 0,15)$ пг/мл, $\left.\mathrm{p}>0,05\right), \mathrm{AC}-$ в 1,32 (до $(2,25 \pm 0,16)$ нг/мл, р<0,01), ДГЕАС - в 1,69 раза (до $(166,6 \pm 11,4)$ мкг/дл, р<0,01), АМГ - в 1,31 раза (до $(5,20 \pm 0,20)$ нг/мл, р<0,01), збільшилася продукція ФСГ $1,20$ раза (до $(6,14 \pm 0,16) \mathrm{MO} / л, \mathrm{p}<0,01)$.

Через 3 місяці після хірургічної стимуляції овуляції у всіх обстежених пацієнток із кломіфен-резистентною формою СПкЯ та ожирінням на 2-3-й день менструального циклу вміст у сироватці крові ЛГ був меншим порівняно з вихідним до операції в 1,13 раза $((8,79 \pm 0,18) \mathrm{MO} / \mathrm{m} л, \mathrm{p}<0,01)$, коефріцієнт співвідношення ЛГ/ФСГ-в 1,44 раза $((1,36 \pm 0,04)$, p>0,05), вміст $E_{2}-$ в 1,26 раза $((46,69 \pm 0,98)$ пг/мл, $\mathrm{p}>0,05), \mathrm{T}_{\mathrm{B}}-1,31$ раза $((2,15 \pm 0,14) п г / \mathrm{м}, \mathrm{p}<0,01), A C-в$ 1,06 раза $((2,50 \pm 0,16)$ нг/мл, $p<0,01)$, ДГЕАС - в 1,29 раза $((188,2 \pm 12,9)$ мкг/дл, $p<0,01)$, АМГ - в 1,27 раза $((5,39 \pm 0,19)$ нг/мл, p<0,01), а рівень ФСГ був більшим у 1,20 раза $((6,56 \pm 0,16) \mathrm{MO} / л, \mathrm{p}<0,01)$. Тенденція до повернення сироваткового вмісту досліджуваних гормонів до вихідного передопераційного рівня посилилася через 6 місяців після проведення хірургічної стимуляції овуляції: так, рівень у сироватці крові ЛГ був нижчий від аналогічного передопераційного в 1,10 раза $((9,02 \pm 0,18) \mathrm{MO} / \mathrm{м}, \mathrm{p}<0,01)$, коефріцієнт співвідношення ЛГ/ФСГ - в 1,47 раза $((1,39 \pm 0,06)$, p>0,05), рівень $E_{2}-$ в 1,31 раза $((48,57 \pm 1,32)$ пг/мл, $\mathrm{p}<0,01), \mathrm{T}_{\mathrm{B}}-1,61$ раза $((2,63 \pm 0,11)$ пг/мл, $\mathrm{p}<0,01), \mathrm{AC}-\mathrm{B}$ 1,19 раза $((2,80 \pm 0,15)$ нг/мл, $р<0,01)$, ДГЕАС - в 1,69 раза $((218,5 \pm 15,0)$ мкг/дл, р<0,01), АМГ - в 1,24 раза $((5,51 \pm 0,08)$ нг/мл, $p<0,01)$, а вміст ФСГ залишався вищим у 1,28 раза $((6,56 \pm 0,16) \mathrm{MO} / л, \mathrm{p}<0,01)$.

Кількість ПРЛ у сироватці периферичної крові до операції, через 1, 3 і 6 місяців після оперативного втручання перебувала в рефрерентних межах і вірогідно не відрізнялася від аналогічних показників контрольної групи.

Поліпшення гормонального статусу безпосередньо після хірургічної стимуляції овуляції привело до настання

Таблиця 1. Динаміка рівнів гормонів сироватки периферичної крові пацієнток із Спкя та ожирінням після

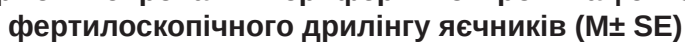

\begin{tabular}{|c|c|c|c|c|c|}
\hline \multirow[b]{2}{*}{ Показник } & \multicolumn{4}{|c|}{ Група з кломісен-резистентним СПКЯ та ожирінням, n=31 } & \multirow{2}{*}{$\begin{array}{c}\text { Контрольна група, } \\
\text { n=30 }\end{array}$} \\
\hline & до операції & $\begin{array}{c}\text { через місяць після } \\
\text { операції }\end{array}$ & $\begin{array}{c}\text { через } 3 \text { місяці після } \\
\text { операції }\end{array}$ & $\begin{array}{c}\text { через } 6 \text { місяців після } \\
\text { операції }\end{array}$ & \\
\hline лГ, МО/л & $9,91 \pm 0,33^{\kappa}$ & $8,20 \pm 0,21^{\mathrm{K}, \mathrm{A}}$ & $8,79 \pm 0,18^{\mathrm{K}, \mathrm{A}}$ & $9,02 \pm 0,18^{\mathrm{K}, \mathrm{A}}$ & $5,30 \pm 0,18$ \\
\hline ФСГ, МО/л & $5,11 \pm 0,20^{\kappa}$ & $6,14 \pm 0,16^{\sharp}$ & $6,56 \pm 0,16^{\text {म }}$ & $6,12 \pm 0,13^{K, A}$ & $3,95 \pm 0,17$ \\
\hline ЛГ/ФСГ & $2,00 \pm 0,09^{k}$ & $1,36 \pm 0,04^{\mathrm{k}, \mathrm{A}}$ & $1,36 \pm 0,04^{\mathrm{K}, \mathrm{A}}$ & $1,39 \pm 0,06^{\mathrm{k}, \mathrm{A}}$ & $1,44 \pm 0,09$ \\
\hline ПРЛ, нг/мЛ & $10,38 \pm 0,49$ & $8,99 \pm 0,51$ & $10,43 \pm 0,47$ & $10,65 \pm 0,50$ & $9,15 \pm 0,53$ \\
\hline $\mathrm{E}_{2}$, пг/мл & $61,09 \pm 3,95^{k}$ & $45,65 \pm 0,95^{\mathrm{K}, \mathrm{A}}$ & $46,69 \pm 0,98^{\mathrm{K}, \mathrm{A}}$ & $48,57 \pm 1,32^{\mathrm{K}, \mathrm{A}}$ & $41,59 \pm 2,33$ \\
\hline Тв, пг/мЛ & $3,45 \pm 0,17^{\kappa}$ & $1,88 \pm 0,15^{\text {म }}$ & $2,15 \pm 0,14^{\mathrm{K}, \mathrm{A}}$ & $2,63 \pm 0,11^{\mathrm{k}, \mathrm{A}}$ & $1,57 \pm 0,12$ \\
\hline АС, нг/мЛ & $2,97 \pm 0,18^{\mathrm{K}}$ & $2,25 \pm 0,16^{\kappa, A}$ & $2,50 \pm 0,16^{\mathrm{k}, \mathrm{A}}$ & $2,80 \pm 0,15^{\kappa}$ & $1,56 \pm 0,06$ \\
\hline ДГЕАС, мкг/ДЛ & $281,5 \pm 19,3^{\mathrm{k}}$ & $166,6 \pm 11,4^{\mathrm{K}, \mathrm{A}}$ & $188,2 \pm 12,9^{\text {к,д }}$ & $218,5 \pm 15,0^{\text {к,д }}$ & $97,7 \pm 6,0$ \\
\hline АМГ, нг/мЛ & $6,83 \pm 0,22^{\mathrm{k}}$ & $5,20 \pm 0,20^{\kappa, д}$ & $5,39 \pm 0,19^{\text {к,д }}$ & $5,51 \pm 0,08^{\text {к,д }}$ & $2,31 \pm 0,05$ \\
\hline
\end{tabular}

Примітки:

1. ${ }^{\text { }}$ - статистично вірогідна різниця з показником контрольної групи, $\mathrm{p}<0,01$.

2. А - статистично вірогідна різниця з досліджуваним показником до операції, $p<0,05$. 
у прооперованих пацієнток вагітності впродовж 3 місяців у 8 (26,81 \%) випадках, впродовж 6 місяців -у 11 (35,48 \%).

Ефект від проведеної хірургічної стимуляції можна пояснити тим, що деструкція фролікулів яєчників і строми викликає зменшення рівня сироваткових андрогенів, у результаті чого відбувається збільшення продукції ФСГ і внаслідок цього відновлюється овуляторна фрункція яєчників $[14,15]$. Крім цього, деструкція частини фролікулярного апарату приводить до зменшення надлишкової продукції АМГ гранульозними клітинами, що сприяє нормальному становленню домінантного фролікула [3] $€$ думка, що внаслідок оперативного втручання посилюється кровопостачання яєчника, що, в свою чергу, сприяє підвищенню доставки гонадотропінів до тканин яєчників. У відповідь на вплив хірургічної енергії при фертилоскопічному дрилінгу яєчників синтезуються місцеві чинники зростання, в тому числі інсуліноподібний фрактор росту-1, які в подальшому здатні посилювати дію ФСГ на фолікулогенез [15, 22].

ВИСНОВКИ. Після проведення хірургічної стимуляції у жінок із кломіфен-резистентною формою СПКЯ шляхом фертилоскопічного оваріального дрилінгу спостерігаєть- ся поліпшення гормонального профілю сироватки перифреричної крові, але через 3 місяці має місце тенденція до поступового повернення вмісту гонадотропінів та статевих стероїдів до вихідного передопераційного рівня. Через 6 місяців після хірургічної стимуляції овуляції найбільш стійким залишається зниження порівняно 3 контрольними значеннями сироваткової концентрації АМГ в 1,24 $(p<0,01)$, Тв - в 1,61 $(p<0,01)$ і ДГЕАС - в 1,69 раза $(p<0,01)$. Поліпшення гормонального статусу безпосередньо після хірургічної стимуляції овуляції привело до настання у прооперованих пацієнток вагітності впродовж 3 місяців у 26,81 \% випадків, впродовж 6 місяців - у 35,48 \%. Отримані дані вказують на те, що перші 6 місяців після хірургічної стимуляції овуляції $€$ найбільш перспективними для планування і настання вагітності у кломіфен-резистентних пацієнток з ожирінням.

ПЕРСПЕКТИВИ ПОДАЛЬШИХ ДОСЛІДЖЕНЬ. ПОтрібне подальше вивчення кореляційних взаємозв'язків сироваткових рівнів гонадотропінів і стероїдних гормонів із рівнями адипоцитокінів для розробки ад'ювантних методик щодо відновлення репродуктивної функції у кломіфен-резистентних пацієнток з ожирінням

\section{СПИСОК ЛІТЕРАТУРИ}

1. Лапароскопическая гистерэктомия у больных ожирением / А. А. Попов, Т. Н. Мананникова, Е. А. Логинова [и др.] // РМЖ. Мать и дитя. - 2015. - № 1. - С. 49.

2. Урбанович А. М. Синдром полікістозних яєчників у щоденній практиці / А. М. Урбанович // Міжнар. ендокринол. журн. - 2018. - № 14 (1). - С. 40-45.

3. Юсубова В. Р. Лапароскопический дриллинг яичников: «за» и «против» / В. Р. Юсубова // Архив акушерства и гинекологии им. В. Ф. Снегирева. - 2017. - № 4 (2). - С. 68-72.

4. Comorbidities and complications of polycystic ovary syndrome: An overview of systematic reviews / E. W. Gilbert, C. T. Tay, D. S. Hiam [et al.] // Clin. Endocrinol. (Oxf). - 2018. Vol. 89 (6). - P. 683-699.

5. Comprehensive evaluation of type 2 diabetes and cardiovascular disease risk profiles in reproductive-age women with polycystic ovary syndrome: a large canadian cohort $/$ M. Kazemi, R. A. Pierson, M. E. Lujan [et al.] // J. Obstet. Gynaecol. Can. - 2019. - Vol. 41 (10). - P. 1453-1460.

6. Fundamental concepts and novel aspects of polycystic ovarian syndrome: expert consensus resolutions / A. Aversa, S. La Vignera, R. Rago [et al.] // Front. Endocrinol. (Lausanne). - 2020. - Vol. 11. - P. 516.

7. Glueck C. J. Characteristics of obesity in polycystic ovary syndrome: Etiology, treatment, and genetics / C. J. Glueck, N. Goldenberg // Metabolism. - 2019. - Vol. 92. - P. 108-120.

8. Han Y. GLP-1 receptor agonists versus metformin in PCOS: a systematic review and meta-analysis / Y. Han, Y. Li, B. He // Reprod. Biomed. Online. - 2019. - Vol. 39 (2). - P. 332-342.

9. Impact of transvaginal hydrolaparoscopy ovarian drilling on ovarian stromal blood flow and ovarian volume in clomiphene citrate-resistant PCOS patients: A case-control study / P. Giampaolino, I. Morra, N. De Rosa [et al.] // Gynecol. Endocrinol. - 2017. - Vol. 33 (9). - P. 690-693.

10. Meta-analysis of gene expression profiles of lean and obese PCOS to identify differentially regulated pathways and risk of comorbidities / S. Idicula-Thomas, U. Gawde, S. Bhaye [et al.] // Comput. Struct. Biotechnol. J. - 2020. - Vol. 18. P. 1735-1745.

11. Mitra S. Laparoscopic ovarian drilling: an alternative but not the ultimate in the management of polycystic ovary syndrome / S. Mitra, P. K. Nayak, S. Agrawai // J. Nat. Sci. Bio. Med. - 2015. - Vol. 6 (1). - P. 40-48.

12. Molecular mechanisms of laparoscopic ovarian drilling and its therapeutic effects in polycystic ovary syndrome I K. M. Seow, Y. W. Chang, K. H. Chen [et al.] // Int. J. Mol. Sci. - 2020. - Vol. 21 (21). - P. 8147.

13. Ovarian drilling by fertiloscopy: feasibility, results and predictive values / J. L. Pouly, M. Krief, B. Rabischong [et al.] // Gynecol. Obstet. Fertil. - 2013. - Vol. 41 (4). - P. 235-241.

14. Ovarian drilling for surgical treatment of polycystic ovarian syndrome: a comprehensive review / H. Fernandez, M. Morin-Surruca, A. Torre [et al.] // Reprod. Biomed. Online. 2011. - Vol. 22 (6). - P. 556-568.

15. Ovarian drilling in PCOS: Is it really useful? / I. Lebbi, R. B. Temime, A. Fadhlaoui, A. Feki // Front. Surg. - 2015. Vol. 2. - Article 30.

16. Pfieffer M. L. Polycystic ovary syndrome: An update / M. L. Pfieffer // Nursing. - 2019. - Vol. 49 (8). - P. 34-40.

17. Pharmacologic therapy to induce weight loss in women who have obesity/overweight with polycystic ovary syndrome: a systematic review and network meta-analysis / F. F. Wang, Y. Wu, Y. H. Zhu [et al.] // Obes. Rev. -2018. - Vol. 19 (10). - P. 1424-1445.

18. Polycystic ovarian syndrome: Correlation between hyperandrogenism, insulin resistance and obesity / X. Zeng, Y. J. Xie, Y. T. Liu [et al.] // Clin. Chim. Acta. - 2020. - Vol. 502. -P. 214-221.

19. Polycystic ovary syndrome is a risk factor for sarcopenic obesity: a case control study / L. E. McBreairty, P. D. Chilibeck, J. J. Gordon [et al.] // BMC. Endocr. Disord. - 2019. - Vol. 19 (1). - P. 70

20. Prevalence, phenotype and cardiometabolic risk of polycystic ovary syndrome under different diagnostic criteria / B. O. Yildiz, G. Bozdag, Z. Yapici [et al.] // Hum. Reprod. - 2012. - Vol. 27 (10). - P. 3067-3073.

21. Prospective evaluation of the learning curve of fertiloscopy with and without ovarian drilling / M. Franz, J. Ott, 
A. Watrelot [et al.] // Reprod. Biomed. Online. - 2015. - Vol. 30 (4). - P. 408-414.

22. Rotterdam ESHRE/ASRM-Sponsored PCOS consensus workshop group. Revised 2003 consensus on diagnostic criteria and long-term health risks related to polycystic ovary syndrome (PCOS) // Hum. Reprod. - 2004. - Vol. 19 (1). - P. 41-47.

23. Sanchez-Garrido M. A. Metabolic dysfunction in polycystic ovary syndrome: Pathogenic role of androgen excess and potential therapeutic strategies / M. A. Sanchez-Garrido, M. Tena-Sempere // Mol. Metab. - 2020. - Vol. 35. - Article ID: 100937. 22

24. The prevalence of polycystic ovary syndrome in reproductive-aged women of different ethnicity: a systematic review and meta-analysis / T. Ding, P. J. Hardiman, I. Petersen [et al.] // Oncotarget. - 2017. - Vol. 8 (56). - P. 96351-96358.

25. Transvaginal hydrolaparoscopy as an outpatient procedure for infertility investigation / S. Gordts, R. Campo, L. Rombauts, I. Brosens // Hum. Reprod. - 1998. - Vol. 13 (1). - P. 99-103.

26. Treatment of infertility in women with polycystic ovary syndrome: approach to clinical practice / A. S. Melo, R. A. Ferriani, P. A. Navarro (2015) // Clinics (Sao Paulo, Brazil). - 2015. - Vol. 70 (11). - P. 765-769.

27. Watrelot A. Evaluation of the performance of fertiloscopy in 160 consecutive infertile patients with no obvious pathology / A. Watrelot, J. M. Dreyfus, J. P. Andine // Hum. Reprod. - 1999. - Vol. 14 (3). - P. 707-711.

\section{REFERENCES}

1. Popov, A.A., Manannikova, T.N., Loginova, E.A., Slobodyanyuk, B.A., Fedorov, A.A., Lysenko, S.N., ..., \&TyurinaS.S. (2015). Laparoskopicheskaya gisterektomiya u bolnykh ozhireniyem [Laparoscopic hysterectomy in obese patients]. Rosiyskiy meditsinskiy zhurnal. Mat i Ditya - Russ. Med. J. Mother and Child, 1, 49 [in Russian].

2. Urbanovich, A.M. (2018). Syndrom polikistoznykh yaiechnykiv u shchodennii praktytsi [Polycystic ovary syndrome in daily practice]. Mizhnar. Endokrynol. Zhurn. - Int. J. Endocrinol., 14 (1), 40-45. DOI:10.22141/2224-0721.14.1.2018.127090 [in Ukrainian].

3. Yusubova, V.R. (2017). Laparoskopycheskiy drilling yaichnikov: «za» $\mathrm{i}$ «protyv» [Laparoscopic ovarian drilling: "for" and "against"]. Arkhiv akusherstva i ginekologii im. V. F. Snegereva - Arch. Obstet. Gynecol. By V.F. Snegerev, 4 (2), 68-72 [in Russian].

4. Gilbert, E.W., Tay, C.T., Hiam, D.S., Teede, H.J., \& Moran, L.J. (2018). Comorbidities and complications of polycystic ovary syndrome: An overview of systematic reviews. Clin. Endocrinol. (Oxf)., 89 (6), 683-699. DOI:10.1111/cen.13828.

5. Kazemi, M., Pierson, R.A., Lujan, M.E., Chilibeck, P.D., McBreairty, L.E., Gordon, J.J., ..., \& Chizen, D.R. (2019). Comprehensive evaluation of type 2 diabetes and cardiovascular disease risk profiles in reproductive-age women with polycystic ovary syndrome: a large canadian cohort. J. Obstet. Gynaecol. Can., 41 (10), 1453-1460. DOI:10.1016/j.jogc.2018.11.026.

6. Aversa, A., La Vignera, S., Rago, R., Gambineri, A., Nappi, R.E., Calogero, A.E., \& Ferlin, A. (2020). Fundamental concepts and novel aspects of polycystic ovarian syndrome: expert consensus resolutions. Front. Endocrinol. (Lausanne), 11, 516. DOI:10.3389/fendo.2020.00516.

7. Glueck, C.J., \& Goldenberg, N. (2019). Characteristics of obesity in polycystic ovary syndrome: Etiology, treatment, and genetics. Metabolism, 92, 108-120. DOI:10.1016/j. metabol.2018.11.002.

8. Han, Y., Li, Y., \& He, B. (2019). GLP-1 receptor agonists versus metformin in PCOS: a systematic review and meta-analysis. Reprod. Biomed. Online, 39 (2), 332-342. DOI:10.1016/j.rbmo.2019.04.017.

9. Giampaolino, P., Morra, I., De Rosa, N., Cagnacci, A., Pellicano, M., Di Carlo, C., Nappi, C., \& Bifulco, G. (2017). Impact of transvaginal hydrolaparoscopy ovarian drilling on ovarian stromal blood flow and ovarian volume in clomiphene citrate-resistant PCOS patients: A case-control study. Gynecol. Endocrinol., 33 (9), 690-693. DOI:10.1080/09513590.2017.13 10837.

10. Idicula-Thomas, S., Gawde, U., Bhaye, S., Pokar, K., \& Bader, G.D. (2020). Meta-analysis of gene expression profiles of lean and obese PCOS to identify differentially regulated pathways and risk of comorbidities. Comput. Struct. Biotechnol. J., 18, 1735-1745. DOI:10.1016/j.csbj.2020.06.023.

11. Mitra, S., Nayak, P.K., \& Agrawai, S. (2015). Laparoscopic ovarian drilling: an alternative but not the ultimate in the management of polycystic ovary syndrome. J. Nat. Sci. Bio. Med., 6 (1), 40-48. DOI:10.4103/0976-9668.149046.

12. Seow, K.M., Chang, Y.W., Chen, K.H., Juan, C.-C., Huang, C.-Y., Lin, L.-T., ..., \& Wang, P.-H. (2020). Molecular mechanisms of laparoscopic ovarian drilling and its therapeutic effects in polycystic ovary syndrome. Int. J. Mol. Sci., 21 (21), 8147. DOI:10.3390/ijms21218147.

13. Pouly, J.L., Krief, M., Rabischong, B., Brugnon, F., Gremeau, A.S., Dejou, L., ..., \& Folini, X. (2013). Ovarian drilling by fertiloscopy: feasibility, results and predictive values. Gynecol. Obstet. Fertil., 41 (4), 235-241. DOI:10.1016/j. gyobfe.2013.02.010.

14. Fernandez, H., Morin-Surruca, M., Torre, A., Faivre, E., Deffieux, X., \& Gervaise, A. (2011). Ovarian drilling for surgical treatment of polycystic ovarian syndrome: a comprehensive review. Reprod. Biomed. Online., 22 (6), 556-568. DOI: 10.1016/j.rbmo.2011.03.013.

15. Lebbi, I., Temime, R.B., Fadhlaoui, A., \& Feki, A. (2015) Ovarian drilling in PCOS: Is it really useful? Front. Surg., 2, 30. DOI: https://doi.org/10.3389/fsurg.2015.00030.

16. Pfieffer, M.L. (2019). Polycystic ovary syndrome: An update. Nursing, 49 (8), 34-40. DOI:10.1097/01. NURSE.0000569748.65796.d1

17. Wang, F.F., Wu, Y., Zhu, Y.H., Ding, T., Batterham, R.L., Qu, F., \& Hardiman, P.J. (2018). Pharmacologic therapy to induce weight loss in women who have obesity/overweight with polycystic ovary syndrome: a systematic review and network meta-analysis. Obes. Rev., 19 (10), 1424-1445. DOI:10.1111/obr.12720.

18. Zeng, X., Xie, Y.J., Liu, Y.T., Long, S.L., \& Mo, Z.C. (2020). Polycystic ovarian syndrome: Correlation between hyperandrogenism, insulin resistance and obesity. Clin. Chim. Acta., 502, 214-221. DOI:10.1016/j.cca.2019.11.003.

19. McBreairty, L.E., Chilibeck, P.D., Gordon, J.J., Chizen, D.R., \& Zello, G.A. (2019). Polycystic ovary syndrome is a risk factor for sarcopenic obesity: a case control study. BMC. Endocr. Disord., 19 (1), 70. DOI:10.1186/s12902-019-0381-4.

20. Yildiz, B.O., Bozdag, G., Yapici, Z., Esinler, I., \& Yarali, H. (2012). Prevalence, phenotype and cardiometabolic risk of polycystic ovary syndrome under different diagnostic criteria. Hum. Reprod., 27 (10), 3067-3073. DOI:10.1093/humrep/ des232.

21. Franz, M., Ott, J., Watrelot, A., Küssel, L., \& Husslein, H. (2015). Prospective evaluation of the learning curve of fertiloscopy with and without ovarian drilling. Reprod. Biomed. Online, 30 (4), 408-414. DOI:10.1016/j.rbmo.2014.12.015. 
22. Rotterdam ESHRE/ASRM-Sponsored PCOS consensus workshop group. (2004). Revised 2003 consensus on diagnostic criteria and long-term health risks related to polycystic ovary syndrome (PCOS). Hum. Reprod., 19 (1), 41-47. DOI:10.1093/ humrep/deh098.

23. Sanchez-Garrido, M.A., \& Tena-Sempere, M. (2020). Metabolic dysfunction in polycystic ovary syndrome: Pathogenic role of androgen excess and potential therapeutic strategies. Mol. Metab., 35, 100937. DOI:10.1016/j.molmet.2020.01.001.

24. Ding, T., Hardiman, P.J., Petersen, I., Wang, F.F., Qu, F., \& Baio, G. (2017). The prevalence of polycystic ovary syndrome in reproductive-aged women of different ethnicity: a systematic review and meta-analysis. Oncotarget, 8 (56), 96351-96358. DOI:10.18632/oncotarget.19180.

25. Gordts, S., Campo, R., Rombauts, L., \& Brosens, I. (1998). Transvaginal hydrolaparoscopy as an outpatient procedure for infertility investigation. Hum. Reprod., 13 (1), 99103. DOI:10.1093/humrep/13.1.99.

26. Melo, A.S., Ferriani, R.A., \& Navarro, P.A. (2015). Treatment of infertility in women with polycystic ovary syndrome: approach to clinical practice. Clinics (Sao Paulo, Brazil), 70 (11), 765-769. DOI:10.6061/clinics/2015(11)09.

27. Watrelot, A., Dreyfus, J.M., \& Andine, J.P. (1999). Evaluation of the performance of fertiloscopy in 160 consecutive infertile patients with no obvious pathology. Hum. Reprod., 14 (3), 707-711. DOI:10.1093/humrep/14.3.707.

Отримано 06.09.20 Прийнято до друку 05.10.20 Електронна адреса для листування: vovachayka1505@gmail.com 